\title{
Money and Morality in the Bolsa Família
}

Talita Jabs Eger

Arlei Sander Damo

\section{Abstract}

This paper brings some findings from research on the meanings of money from Brazil's Family Grant Program (Programa Bolsa Familia, PBF). The ethnography on which it is based was carried out between 2010 and 2012 in the cities of Alvorada and Porto Alegre. It shows, firstly, that even though it is received in cash, the PBF money is not just an abstract mediator. Rather, access to this kind of money, or to the PBF itself, is accompanied by a series of moral values that go beyond the legal conditionalities that characterize the program. Drawing on ethnographic instances, our discussion highlights some of the key elements of this morality: negotiations around the notion of vulnerability (a central concept for the social workers in charge of enrolling beneficiaries in the PBF), and the different meanings of the PBF money, from the beneficiaries' point of view. This diversity of meanings is presented synthetically in terms of some key domains: money of women and for women; money of children and for children; money interdicted and shameful to men. Keywords: Bolsa Família (Family Grant), money, morality, anthropology, public policy.

\section{Resumo}

Este artigo é resultado de uma investigação acerca dos significados do dinheiro do Programa Bolsa Família (PBF). A etnografia que está na origem deste texto foi realizada entre 2010 e 2012 nas cidades de Alvorada e Porto Alegre. O objetivo mais amplo da investigação foi mostrar como o dinheiro do PBF, em que pese seja recebido em espécie, não é um dinheiro simples mediador abstrato. Pelo contrário, o acesso a este dinheiro ou, preferindo-se, ao PBF, 
vem acompanhado de uma série de valores morais que extrapolam, consideravelmente, as condicionalidades legais que caracterizam o programa. A partir de casos etnográficos, destacamos os aspectos centrais atinentes a esta moralidade: a negociação em torno da noção de vulnerabilidade, um conceito central para as assistentes sociais responsáveis pela inclusão de beneficiários no PBF, e os diferentes significados do dinheiro do Bolsa segundo o ponto de vista dos beneficiários. Com a finalidade de apresentar as informações de forma sintética agrupamos a diversidade dos significados em alguns eixos principais: dinheiro das e para as mulheres; dinheiro das e para as crianças; dinheiro interdito e vergonhoso aos homens.

Palavras-chave: Bolsa Família; dinheiro; moralidade; antropologia; políticas públicas. 


\section{Money and Morality in the Bolsa Família}

Talita Jabs Eger

Arlei Sander Damo ${ }^{2}$

\section{On national guidelines and local implementation}

The Bolsa Família Program (PBF) was launched in 2003 as the consolidation of multiple income transfer programs from the Brazilian federal government. It sought to increase the value of benefits and broaden the scope of welfare protection to low-income families - thus becoming one of Brazil's main social policy instruments (SANT'ANA, 2007; SOARES and SÁTYRO, 2009)3. After one decade and a few changes and extensions, in 2013 the program had benefited over 13 million families, and invested around 31 billion dollars. Due to its wide scope and bold strategy of delivering cash directly to the poor (in a policy domain where the most common is to provide basic goods), the PBF is today one of the world's largest Conditional Cash Transfer Programs (CCTP) in terms of coverage, and one of Brazil's chief instruments of social protection (SOARES and SÁTYRO, 2009; POCHMANN, 2010). Even though it is broadly associated with the administration of former President Lula (2003-2010), the PBF is part of a longer trajectory of social protection policies in Brazil. The 1988 Constitution was a particularly salient landmark, as it established basic guidelines for building a new social protection system ${ }^{4}$.

1 Talita Jabs Eger holds an M.A. from the Federal University of Rio Grande do Sul (UFRGS). She is an associ-
ate researcher at the Research Nucleus on Contemporary Cultures (Núcleo de Pesquisa sobre Culturas Con-
temporâneas, NUPECS), and a member of the Anthropology of Politics and the Economy Group (Grupo de
Antropologia da Economia e da Política, GAEP), both based at UFRGS. She has worked on the following topics:
Urban Anthropology, Economic Anthropology, Family Grant Program, Low Income Groups, Solidary Economy,
and Finance. Email: talitaeger@uol.com.br. 2 Arlei Sander Damo is Professor in the UFRGS's Social Anthropology Graduate Program. He has carried out research in the fields of Anthropology of Sports, Anthropology of Politics and the Economy. He holds a Level 2-“Productivity in Research” Grant from CNPq. Email: arleidamo@uol.com.br.

3 It only has fewer beneficiaries than Brazil's Unified Health System (Sistema Único de Saúde, SUS), public education, and Social Security (SOARES and SÁTYRO, 2009).

4 It promoted social assistance to the same status as other social policies (for education, health, social security), for instance, by recognizing rural workers' right to retirement without full contribution, and instituting 
The first CCTPs implemented in Brazil operated at the municipal and federal levels. In 1995, the cities of Campinas, Brasília and Ribeirão Preto established programs targeting families with children, conditional on their regular school attendance. In 1996, the first federal CCTP was created: the Child Labor Eradication Program (Programa de Erradicação do Trabalho Infantil, PETI), aimed at children and adolescents at risk of being forced to work (or who already worked) in order to help provide for their families. This program was part of the State Secretariat for Social Assistance, and its purpose was to "encourage children and adolescents to quit hard labor for school” (SILVA E SILVA et al, 2009:103). In 2001, the second CCTP came about: the National Minimal Income Program. Best known as "School Grant", it targeted children between 6 and 15 years old, and demanded from beneficiaries minimal school attendance of $85 \%$. At about the same time, the Ministry of Health launched the Food Grant Program, which was aimed at children between o and 6 years old, and required from beneficiaries commitment to breastfeeding, pre-natal exams for pregnant women, and vaccination for the children. Another program was the "Gas Aid", established in 2002 by the Ministry of Mines and Energy, and the Food Coupon launched the following year, aimed at families at risk of food insecurity earning less than half a minimum wage. In order to optimize management of all these programs - and the trend at the time was for each sector to institute its own CCTP - the Bolsa Familia Program was established as the unification of the School Grant, Food Coupon, Food Grant, and Gas Aid (in 2005, it came to include the Child Labor Eradication Program).

Thus, before the PBF, Brazilian conditional cash transfer policies were implemented by multiple agencies, based on different information systems and funding sources. As a result, families with very similar socio-economic statuses received different kinds of transfer (SILVA et al, 2008; SILVA, 2009; SOARES, 2009), depending on the way they were framed. With the new program, managers sought, on the one hand, to "homogenize eligibility criteria, benefit values, implementing agencies, and information systems" (SOARES, 2009:7) by integrating all these programs and increasing the value of the cash benefits. On the other hand, they sought to exclude intermediary

solidarity (that is, non-contributive) income for elders and handicapped living under economic vulnerability (the Continuing Benefit Conveyance program). 
politicians (mayors, first ladies, and so forth) who were common channels for resource embezzlement, since the funds coming from the federal government were transferred to local agencies before being distributed to beneficiaries.

Even after unification, municipalities have continued to play a key role in the PBF: they are in charge of identifying and registering low-income families, ${ }^{5}$ and keeping up to date the Unified Registry of Federal Social Programs (CadÚnico). ${ }^{6}$ They are also responsible for monitoring and sending data to the federal bank Caixa Econômica Federal (CEF); for providing basic services involved in the conditionalities that have to be met by the beneficiaries (schools, health clinics, Social Assistance Centers); and for producing reports on the effective compliance to the program's conditionalities ${ }^{7}$ - that is, the beneficiaries' returns and duties. Finally, they disseminate information on the program and on eligibility criteria for low-income families. The municipalities therefore operate as the PBF's "gateway". Therein lies the relevance of identifying local implementation strategies, understanding them as a set of actions shaping not only the provision of services to the beneficiaries, but also the paths that families must travel in order to enroll, and remain enrolled, in the program.

Conditionalities are one of the chief elements of this intervention model; they are taken up both by the beneficiary families (who must abide by them) and by state agencies at the municipal level (in charge of delivering health, education, and social assistance services). Their avowed purpose, according to the program's local implementers, is to guarantee access by these families to "basic social services". According to the program's managers, its chief objective is to enhance the beneficiaries' "human capital", thus breaking "poverty's inter-generational cycle". The implementation of the PBF is regarded as a positive step in the trajectory of Brazil's welfare policies, since its actions are focused on the family instead of its individual members (POCHMANN, 2010:15). The funds are however especially directed to the women, and the conditionalities target children, adolescents, and pregnant and/or breastfeeding women - the program's conception of the family

5 That is, those with a monthly income of less than half a minimum wage per person (around U\$150).

6 CadÚnico aims at identifying all low-income families in Brazil - besides, according to official discourse, sharpening the focus of social programs targeting the poor.

7 While some consider conditionalities as providing access to basic social rights, others regard them as a denial of those rights. 
therefore leaves out the men, as if they were not part of it.

With respect to education, for instance, families must keep children between 6 and 15 years old enrolled in school, showing minimal attendance of $85 \%$ (for adolescents between 16 and 17 years old this figure is of $75 \%$ ). In the domain of health, families make a commitment to keep up with the vaccination schedule, and monitor the growth and development (through weight and height) of children under 7 . In contrast with the boys, girls over 7 must continue to abide by the health conditionalities. This is also the case of women of reproductive age (up to 49 years old), and when they are pregnant and/or breastfeeding, they are required to undergo regular prenatal exams and checks on the baby's health. In the realm of social welfare, it is the family's duty to refer children and adolescents under 16 (who are at risk or who have been removed from child labor by the PETI) to the PETI's Coexistence and Bonding Services (Serviços de Convivência e Fortalecimento de Vínculos, SCFV), where they should maintain an attendance rate of at least $85 \%$. They must also take part on activities offered by the Social Assistance Reference Center (Centro de Referência de Assistência Social, CRAS) and/ or a Specialized Social Assistance Reference Center (Centro de Referência Especializada de Assistência Social, CREAS), and re-register every two years (maximum) by providing all family members' full documentation.

The values in cash transferred by the BPF are based on poverty thresholds and family membership (i.e., whether there are pregnant or breastfeeding women, children and adolescents under 15, or juveniles between 16 and 17). Thus, families may receive up to three kinds of benefits, whose aggregated value may range between $\mathrm{R} \$ 32,00(\mathrm{U} \$ 13,6)$ and $\mathrm{R} \$ 306,00(\mathrm{U} \$ 130,3)$ : the basic, the variable (depending on the number of children), and the youth variable (depending on the number of adolescents). Families considered "poor" are not eligible for the basic benefit (R\$ 70 [U $\$ 29,8])$, and cannot receive more than $\mathrm{R} \$ 236(\mathrm{U} \$ 100,5)^{8}$. Families considered “extremely poor”, on their turn, may receive the basic as well as the variable benefits - thus often reaching the maximum possible value of $\mathrm{R} \$ 306(\mathrm{U} \$ 130,3)$.

During its decade-long existence, the PBF has been the subject of significant commentary both in the press (especially critical or complimentary

8 According to World Bank criteria, the Brazilian government considers as "extremely poor" families whose per capita monthly income is less than R $\$ 70$ (or U $\$ 29.8$ ). The World Bank considers those who survive with less than one dollar per day as indigents. 
perspectives during election years $)^{9}$ and in academia. ${ }^{10}$ In spite of the program's extraordinary breadth and controversial character, ethnography-based studies are rare. Here, we will argue that the PBF money, even if received in cash, is no simple abstract mediator. On the contrary, access to that cash (or to the PBF itself) implicates a series of moral values that extrapolate significantly the legal conditionalities on which the program is based. Based on ethnographic observation, we will underscore central aspects of this kind of morality: negotiations around the notion of vulnerability (a key concept for the social workers in charge of enrolling beneficiaries in the PBF), and the multiple meanings attributed to the Grant's cash from its recipients' point of view. In order to present our data synthetically, this diversity of meanings will be grouped as: money of and for women; money of and for children; money interdicted and shameful to men. This study is based on ethnographic fieldwork carried out between 2010 and 2012 in the town of Alvorada, in Porto Alegre's metropolitan region, ${ }^{11}$ supplemented by interviews conducted among beneficiaries living in the Ilha da Pintada (Porto Alegre). ${ }^{12}$

The municipality of Alvorada is located around one hour drive from downtown Porto Alegre, capital city of Rio Grande do Sul. According to 2010 data from the Brazilian Institute of Geography and Statistics (IBGE), it includes 195,718 people living in an area of 70,811 square kilometers. Its per capita Gross Domestic Product is $\mathrm{R} \$ 7,528$ (around U\$3,206), according

9 Criticism may range from a conviction that the PBF should be stricter when enforcing conditionalities (since the legitimacy of transferring income to potentially economically active individuals is often at stake) to arguments against their relevance, given the "vulnerability" of beneficiary families. In the latter case, the issue is whether the Family Grant is indeed a right - being considered by some, including in academia (MEDEIROS, BRITTO and SOARES, 2008; COHEN, 2012), as a "quasi-right". As Cohen (2012: 10) argued, inasmuch as its budget is well defined and its character is temporary, it would constitute an "unstable" benefit, especially when compared with transfers channeled for instance through social security.

10 In this respect, it is worth remarking the interdisciplinary work of the Study Group on Poverty and Povertyrelated Policies, based on the Federal University of Maranhão (GAEPP: http://www.gaepp.ufma.br/site/); literature found in the PBF Virtual Library; and a recent special issue on the 10 years of the PBF of the Revista Politica e Trabalho (n.38, April 2013). In the social sciences, we would add the studies by Souza (2007), Rabelo (2011), and Ávila (2013).

11 This article is based on the M.A. thesis of Talita Jabs Eger (EGER, 2013), written under the supervision of Arlei Damo in the UFRGS's Social Anthropology Program.

12 Some adversities faced during fieldwork made it necessary to change field sites. Based on recommendations by friends and acquaintances, we ended up at Ilha da Pintada, in Porto Alegre. In this case, the aim was not to follow the social protection network as it was done in Alvorada, but to talk to families living in a different municipality - and therefore, immersed in other social configurations and relations - in order to probe into diverse understandings on the PBF cash, or, conversely, to corroborate the discourses gathered in Alvorada. 
to the Economy and Statistics Foundation ${ }^{13}$, and its Human Development Index according to the United Nations Development Program (UNDP/2010) is 0.6999 - that is, a Medium Human Development index ${ }^{14}$. According to 2013 quantitative data on the PBF (from the Federal Government's PBF and Social Programs Unified Record ${ }^{15}$ ), in January that same year the municipality had 12,750 families registered in the CadÚnico, and the number of poor families ${ }^{16}$ as defined by the $\mathrm{PBF}^{17}$ was 9,324. Of these, around 7,619 were benefited by the PBF - in other words, program coverage in the municipality was of $81.7 \%$. It should be highlighted that, until recently, the municipality (which was emancipated in 1952) did not have an organized database on its history and its residents' ethnic and cultural make-up. Alvorada has been popularly known as a "dormitory" or "passage" town, and even thought (according to its residents) this characteristic has been changing ${ }^{18}$, it does not yet have an identity beyond what is described in statewide media as "lawless land"19. This stigma, which has been continuously produced and nourished by high poverty and crime rates, somewhat influences the way the PBF is managed in Alvorada.

\section{A special kind of money}

During its ten years, the PBF has been subjected to multiple criticisms: for transferring cash directly to families; for its eligibility criteria (the chief criterion, income, is self-declared); and, most fundamentally, for its conditionalities. But in the press and among beneficiaries, none of these is as common as questions regarding the latter's capacity to manage the funds they receive.

13 Cf. http://www.fee.tche.br/sitefee/pt/content/resumo/pg_municipios_detalhe.php?municipio=Alvorada. Last accessed, August 02, 2013.

14 Cf. http://www.atlasbrasil.org.br/2013/perfil/alvorada_rs. Last accessed, August 02, 2013.

15 The Report is available at: http://aplicacoes.mds.gov.br/sagi/RIv3/geral/relatorio_form. php?p_ibge $=430060 \&$ area $=0 \&$ ano_pesquisa $=\&$ mes_pesquisa $=\&$ saida $=$ pdf $\&$ relatorio $=153$ $\& m s=585,460,587,589,450,448,464,601$. Last accessed, April 4, 2013.

16 Based on the 2010 Census.

17 According to the program's guidelines, "extremely poor" families are those with a monthly per capita income below R \$70, and "poor" families are those with a monthly per capita income ranging from R \$70,01 to R $\$ 140$.

18 With the current expansion of local business, a significant share of the population is employed within the municipality.

19 Beginning in the decade of 200o, public managers and residents of Alvorada engaged in an effort to "construct" an identity for the city removed from this image of violence. They supported the publication of books reconstructing the municipality's history based on oral accounts, doubled the number of local newspapers, (online) community radio stations, and so forth. 
To a large extent, such criticism is addressed to spending on arguably superfluous items, presumed embezzlement, underestimation of income by the beneficiary families, and especially misspending - a notion based on certain assumptions about the appropriate ways to spend certain kinds of cash. These critiques suggest two opposite and complementary directions: the money's origin and destination, that is, from the public purse to the pockets of the "poor". This brings to surface judgments, tensions, and negotiations stemming less from utilitarian issues than from the moral management of these funds - or yet, to the imbrication between these two dimensions.

Another point can be made regarding the cash that is received as benefit. The program's guidelines restrict its target population (in terms of age, poverty lines, and so forth), but make no reference as to how people should spend the money. Although the federal government has produced brochures discussing the advantages of having a bank account and the importance of appropriately managing money, the notion of appropriateness deployed is quite vague, and it is rarely discussed among the PBF agents and between them and the beneficiaries. The latter have full legal autonomy to spend the cash as they wish, as long as conditionalities are met. There are however social constraints that impose behavioral parameters on the beneficiaries more or less directly, stemming from everyday interactions with relatives, neighbors, school agents, or the local social protection network. These involve multiple discursive ways of asserting "more" or "less" appropriate ways of spending the PBF cash. Meanings attributed to this kind of money are shaped by existing social relations (for instance, gender relations), and, from our analytical perspective, they can on their turn help re-signify and remodel those relations.

The PBF is therefore a fertile terrain for thinking about a kind of money that not only comes from a government program (that is, public money), but that is directed to a particular social group (the "poor") whose behavior, life and consumptions styles have been continuously stigmatized ${ }^{20}$. Cash from the Family Grant is therefore socially different from other kinds of money, inasmuch as it is transferred by the state, is put preferably under the tutelage of (low-income) $)^{21}$ women, and, lastly, is aimed at including children

\footnotetext{
20 The social sciences literature discussing uses of money by the "poor" or "popular" groups is significant. For an updated discussion, including a review, see the studies by Muller (2009) and Wilkis (2013).

21 Nationwide, women comprise $93 \%$ of the program's cardholders.
} 
and adolescents in certain educational, health and welfare initiatives. It is therefore a kind of money that is loaded with class, gender and generational markers, as well as socially constructed meanings, moralities, classifications, and expectations that are being constantly tensioned.

We therefore consider the PBF cash to be a "special kind of money", in Zelizer's terms (1994; 2003; 2011): it is pervaded by different and sometimes controversial meanings, norms and expectations, from early discussions undergirding the program's policies until its entrance in the beneficiaries' home. In this scenario, marks, classifications and moralities are produced, which relate not only to that money's source and destination, but also to the identity of its recipients. Various circuits emerge from the process of constructing the program (ZELIZER, 2005), since its framework prompt the articulation of multiple actors, and therefore continual communication and tensioning of meanings, classifications, values, emotions, moralities, and so forth. In this sense, the program's money operates as a vector that gathers together all these elements. The assemblage of these various circuits (and their respective actors) around the program becomes important, because they function as mediators between the PBF managers and the beneficiaries. In this sense, criticisms addressing how the latter spend that money emerge most forcefully from the social, economic, and solidarity relations of which they are part.

At this point, it is useful to elaborate on some of these relations. Firstly, family relations within the household play a key part in the attribution of meaning to the PBF money. Secondly, there are those relations entertained with other groups, such as those responsible for the actions associated with the program's conditionalities: schools, daycare, philanthropic institutions, NGOs, public health services, and so forth. Among these multiple agents and institutions, we chose to privilege the relationships between the PBF beneficiaries and the CRAS social workers. The latter have the power to decide on who is to be included or excluded from the program, besides showing a discursive repertoire on how the program's money should be spent. As a rule, these discourses are strongly marked by moral judgments, which intersect and run in parallel with the beneficiaries' own points of view. As much, or even more, important than the PBF monetary economy are issues pertaining to a moral economy, understood here as the management of a heterodox set of orientations tracing a sometimes faint line between what should and what 
should not be done with the PBF cash. Our notion of moral economy was drawn from Fassin (2010; 2011 and 2012), and supposes that the program's beneficiaries have at their disposal a broad range of possibilities for justifying an equally broad range of uses to which the PBF money may be put. Ultimately, however, they cannot do without some justification, since this money is not viewed as belonging to the cardholder - that is, the individual who has legal access to the program's resources ${ }^{22}$.

Depending on how we look at it (or on the circuit of which it is part) the PBF money may be conceived in terms of different categories. It may be cash "for the poor", "for women”, “of women”, "for children”, “of children” (as will be seen below), and so forth. These social (or emic) categories not only define the relationships that permeate this cash; they are themselves shaped by the social relations in which the beneficiaries are immersed, and their outlines are defined according to the moral configurations around which this money is assembled. Thus, the latter may vary depending on how they are organized and adjusted, for instance within domestic nuclei and in terms of the compositions and interactions within welfare networks. In Alvorada, these networks include state agencies providing social assistance services (the CRAS), partner entities of the Social Assistance Unified System (Sistema Único de Assistência Social, SUAS), and poorly formalized entities, organizations and agents who operate at a local level providing social protection actions and care.

\section{On tensions and negotiations between beneficiary families and social workers}

In Alvorada, access to the PBF happens through CRAS units, the program's "official gateway". Before being entered in the CadÚnico, each family must be "enrolled in the CRAS" that has jurisdiction over its neighborhood, and then be seen by a social worker. This professional is in charge of making early assessments on the applicants' socio-economic status and their eligibility for the program. This visit is normally held after the families go to the CRAS,

22 Particularly important for our argument is Fassin's notion of "moral economy" as a non-monetary economy, that is, a way of managing the "production, distribution, circulation and consumption of emotions and values, norms and obligations in the social space" (FASSIN and EIDELIMAN, 2012: 9). On the influence of James Scott and E.P. Thompson on his formulation, see Fassin (2012:19-47). A slightly different, but equally insightful, notion of moral economy can be found in the work of Fontaine (2008). 
but according to those running the program locally, in some cases, when there are doubts about the information provided to the CadÚnico, or when the record is not approved by the $\mathrm{CEF}^{23}$ technicians, a new "household visit" is required ${ }^{24}$. This visit aims at assessing living conditions and the durable goods owned by the family, in order to verify the information declared by the applicants. Even though the technicians who carry it out do not consider it to be an "investigation", it is common for them to seek further information on the applicants among their neighbors and relatives.

The CRAS is in charge of monitoring the families enrolled in the program. These (mostly female) professionals are therefore in charge not only of offering and following up on some of the services prescribed by the conditionalities. As they carry out their task, they make judgments on how the beneficiaries should deploy the grant, and commonly draw on eligibility criteria that stray from formal program guidelines. While the PBF norms are based on delimitation by income and its categorization according to so-called "poverty lines", social workers often act based on notions of "vulnerability" as key eligibility criterion. This notion has become current in the universe of social assistance (beyond the PBF), and is indeed a flexible category, which can be refashioned and adapted to multiple situations. The absence of men or providers is no doubt a major marker for characterizing a family or person as "vulnerable". Since the concept may be deployed broadly, the very subjects who are the target of the intervention - the "poor" - have assimilated it, thus constructing appropriate narratives and performances in their quest to become beneficiaries. This strategy must be deployed carefully, however, because "vulnerability" in excess may end up legitimating more radical kinds of intervention by the state apparatus, such as jailing spouses (in case of violence against women) or damaging one's status within the local community (especially in those cases where the household nucleus includes a man who is potentially able to provide for his family but fails to do so).

23 The CEF is both a payer and operator agency. The bank is in charge not only of paying the benefits; it also runs the program through the CadÚnico - more precisely, it automatically selects from its records those families that are eligible for receiving the benefits according to the program's criteria.

24 After the preliminary registration process is successfully completed, every fifteen days the data gathered by the social workers is transferred to the CadÚnico agency in the municipality. Within two days, they are included in the system, and within 48 hours the CEF issues a Social Identification Number (NIS). The estimate for receiving the benefit ranges from 1 to 6 months, according to the agents with whom we spoke. This waiting period is attributed to the fact that the CEF runs records automatically, in such a way that those with lower income are cleared first, thus receiving their cards and payments before the others. 
The composition of the household is therefore a key element in determining eligibility. On the one hand, the PBF aims at benefiting families by transferring income and supporting access to basic social rights (by articulating the domains of health, education, social assistance and complementary actions and programs). On the other hand, there is a clear focus on women, who comprise the majority of cardholders (in Alvorada, they account for 97\%), and on children and adolescents, who benefit from public services through the conditionalities. The actions promoted by the PBF are therefore sharply delimited in terms of gender and generation, keeping men at a distance from welfare programs and activities. But the families also play a major role in this process: in terms of the information to be included (or not) in the CadÚnico on the one hand, and of the negotiations over (and sometimes, resistance against) their participation in the activities and actions promoted by the CRAS, on the other. These are common causes of tension between the beneficiaries and the social workers.

During fieldwork, especially when following the social workers, observations were carried out in two out of five CRAS centers located in Alvorada. During the household visits, we observed disputes, tensions and negotiations between the beneficiary families and the social workers. Confrontations usually stemmed from the beneficiaries' attempts at resisting some intervention caused (or promoted) by the workers. In all cases, questions regarding the moral economy pervade the actions of social workers, and may be unveiled during unsuspected circumstances - as can be seen in the episode that will be recounted as follows.

One day, one of the of the municipalities' older social workers, Daniele ${ }^{25}$, talked about the history of social assistance in Alvorada, when young Manoela silently entered the room holding a baby. Daniele stood up abruptly and ran towards the door to embrace her. They held each other enthusiastically, and exchanged words of affection. Suddenly, Daniele asked harshly, "Whose baby is this?" Smiling, Manoela answered that it was hers, and that she was there to show it to Daniele. Daniele then declared to be upset with the girl, because she had not taken the "necessary precautions" for avoiding pregnancy, thus wasting an "important time" of her life and jeopardizing her "education". Faced with such scolding, Manoela just stood there,

25 In order to protect the identity of our research subjects, all names included here are fictional. 
impassive. All of a sudden, for everyone's surprise, she burst into laughter. In fact, Manoela had taken part in numerous projects offered by the CRAS during her childhood and adolescence, always under Daniele's supervision. Daniele, on her turn, felt like "a mother" to the girl, and offered her personal advice besides her regular work duties - related, for instance, to avoiding early pregnancy. This advising had been so recurrent that Manoela thought it would be funny to give the social worker "a scare" by showing up with a baby, who turned out to be her godson. The performance would not be complete if Manoela had not in fact continued to study and work, "as always". After this grand finale, Daniele was visibly relieved: "Thank God!".

Even though situations such as this were routine in the CRAS, the everyday of social workers included real tensions, triggered especially during their regular "household visits". One exemplary case is that of Cigana. Although she had gone to the CRAS in order to solicit the visit as a condition for applying for a basket of basic staples, she was overtly upset about the social workers' (sometimes invasive) actions. Ultimately, her complaints got to a point of refusing the provision of a kind of food offered by the workers. During the visit, she was questioned about why she would not accept a package of frankfurters, to which she answered straightforwardly: "Never! I would never eat that. It's egum food!"'26.

Not all encounters between social workers and beneficiaries are characterized by open conflict, however. Much to the contrary: most are permeated by veiled tensions, by the unsaid, gazes that do not meet, lowered heads, and unfathomable sighs. It was interesting to observe how people negotiate their participation in the actions promoted by the workers, and the constant tension that pervades these relations. The workers justify their intervention on the grounds that continuous monitoring would help reduce the "vulnerability" of families, since they act (or should, according to their own perceptions) as mediators between the families and other public services. Families, on their turn, submit themselves to the intervention of social service when they recognize an ultimate need, or when they seek access to a particular kind of "right" or service. Normally, they approach the social workers and public service units when they are in need of punctual, immediate solutions, such as bus tickets, basic staples, documental evidence of their condition of

26 In candomble, egum is an entity associated with the spirits of the dead. 
"poverty" or "vulnerability", submission of I.D. documentation, and so forth. The workers, on their turn, attribute this "short term" view to the way social service agents have operated in the country during the last decades (especially prior to the 1988 Constitution). Thus, in Alvorada, social workers have not had the necessary conditions for appropriately carrying out the intermediation between families and other public services, and this largely explains the former's skepticism towards the effectiveness of their actions.

\section{The language of suffering: from "poverty" to "vulnerability"}

It is interesting to remark that, even though the PBF's chief criterion is income (which demarcates poverty lines), in practice, when registering new beneficiaries, the social workers do not carry out "visits" in search neither for "the poor" (as defined by the program framework), nor for "the poorest among the poor" (according to the focusing principle); they go, rather, after the "vulnerable". As we understood it, this stemmed from the principles guiding the actions of social service. The Social Assistance Organic Law (Lei Orgânica de Assistência Social, LOAS) establishes social assistance as a right for Brazilian citizens. But inasmuch as it is directly to those that, by principle, lack access to basic rights, targeted subjects are required to provide evidence of this condition before applying to social services. Social workers are well aware of debates around the PBF in the public sphere (regarding poverty, the preferential channeling of resources to women, concerns about services provided to children). But they are not passive implementers of the moral values and expectations implicated in the program. If, on the one hand, their actions unfold from the measures and controls prescribed in the program framework, on the other they align the services they provide and the relationships they build through the PBF with the moral principles orienting the circuit they constitute along with the subjects of their interventions.

In addition, the "eligible" (potential beneficiaries) show an effort to demonstrate or validate their own needs. Let us bring back Cigana, a 35-year old, unemployed mother of five, who went to the CRAS in order to request a basket of basic staples. The workers, who faced high demand for a limited amount of baskets, had to "run visits" carrying along the baskets and the addresses of those who had been identified as "priorities" after having visited the CRAS - a status to be confirmed by the visit. In this context, the 
applicants had to demonstrate that their poverty was worse, truer, more intense and urgent than the poverty of others. And so it was with Cigana. The social workers' task was to find evidence of what Cigana had stated two days earlier in the CRAS: even though a recipient of the PBF benefit, she still could not provide for her family. The visit to her home aimed at double-checking the veracity of her claims. Sitting in front of her, a social worker and a psychologist inquired about her current situation: was she still married? How many children did she have? Where were they? How many lived with her? Why did she keep on having children? Did the husband work? On what? What about her, did she work? Why not? And finally, why did she seek the CRAS?

Cigana answered the questions while trying to find points of entry for reasserting the precariousness of her living conditions. Between one answer and another, she would move around the kitchen, opening and closing cabinets, showing inside the fridge and the stove, showcasing empty pans: “Come and see! Look, I have nothing here. I'm not lying! Come and see!”. Faced with the workers' refusal to take part in the proposed interaction, claiming that the conversation was still ongoing, Cigana called her three-year old daughter Bianca. She then pulled the girls' pants up to the knees, pointing to her skinny legs. Cigana needed one basket of staples, and got it. As we moved towards the street in order to get the staples from the city vehicle that accompanied us, she asked what was in the basket. "Rice, beans, pasta, sweet and salty crackers, coffee, wheat flour, soybean oil, sugar and salt", the worker replied. Before we said goodbye, we heard "wow, that's great! I haven't had coffee in fifteen days". She then offered us a last piece of evidence of her "vulnerability" by immediately handing over to Bianca a package of crackers.

In another occasion, we went to a house headed by a "single mother", who had requested to be enrolled in the PBF. The social workers were doubtful about some of the information she had provided, thus deeming the visit necessary. When arriving at the gate, the agent declared, sarcastically: "This one thinks she'll deceive us. Look at her house. It's obvious that she doesn't need it!". Once inside the house, after a set of questions regarding family, professional and financial conditions, we wrapped up the visit certain that that case would be "archived". According to the social worker, besides the many questions she asked, she also observed the house, the furniture, the clothes the mother and the children were wearing - they were among those who "don't really need [the benefit], but try to take advantage of it”. 
Another instance revealing of relations between "poverty" and "vulnerability" - and about money and morality - was that of Maria Rosa ${ }^{27}$. While her economic status made her eligible to enrollment in the PBF, other indicators undermined her case. A 46 year-old mother of three, she lived with her youngest, 13-year old daughter in a "small, simple but clean" apartment, as she used to say. After divorcing her first husband, Maria Rosa experienced sharp financial decline. While she was married, she lived in a duplex apartment in one of Porto Alegre's most expensive neighborhoods. According to her, she had "employees, cars, properties... everything in the plural”. After divorcing, she kept the couple's apartment; however, influenced by her new husband, she exchanged it for a house, which she ended up loosing during her second divorce. Since then, Maria Rosa and her daughter have lived off of donations and the Family Grant. They received donations of clothes (including underwear - something she highlighted quite often), food, furniture, bus tickets, and medicine. The apartment where she lived, located in a middle-class neighborhood in Porto Alegre, had been donated by her father. Her family helped as best as they could: through donations, hiring her as a house cleaner every once in a while, but never directly, "through money". In a way, Maria Rosa felt responsible for what happened, and that was why her family would never give her any cash. Since she did not have any income, she was therefore eligible according to the PBF economic criteria - and she was, indeed, a beneficiary of the program. The few times she went to the CRAS, she claimed, "people looked at me as if I was an alien. They glanced sideways. As if I was not meant to be there". Maria Rosa was indeed an upright woman, head always up high with a firm glance, impeccable hair. Her simple, slightly faded clothes almost go unnoticed. Indeed, she did not look, behave, move, gesture, speak and dress as most CRAS "users". She definitely did not fit the "poor" stereotype, and she was well aware of that. "People cannot believe that I have it rough. I've talked, explained, recounted my situation, but there's no use", she said. The way she found of lending a truth aura to her story was to keep a good record of all documents demonstrating the unfortunate loss of her house. Her poverty could be confirmed by the numerous documents she carried along, and exhibited regardless of her interlocutors' will. What Maria Rosa did not know, however, is that the very lack of documents is, from 
the social workers' perspective, an eloquent demonstration of vulnerability. Based on the PBF characteristics, and the way the social workers mediate this public policy, one is led to infer that dispossession is the chief gateway to the program. The notion of "right" - which, as a rule, accompanies public policies, as Biehl (2013) has shown for patients in need of special drugs who access them through legal means - only figures very faintly in the case of the PBF. The view that the Family Grant cash is a kind of "aid" is much more common than references to it as a "right" - what suggests an interpretation of the PBF as pervaded by a moral gift economy.

When asked about how she felt about her "new" social and financial situation, she affirmed to feel "bad, sad, desolate, and hopeless". But whenever she went to the CRAS or to the church (which offers donations), she became aware that her situation was not "that bad" after all. "There's people in much worse off than me. (...) These [women] who go to the CRAS, for instance, they are always dirty, wearing filthy clothes. They are poorer than I am. (...) If I walked around as dirty as them, the social workers would believe me". In this context, the language of suffering (MELLO, 2011), triggered by the relationship between beneficiaries and social workers, is aimed not only at redressing vulnerabilities, but producing them. This is an important point since, when the social workers were not around, none of our interlocutors defined themselves as "poor" when asked about their financial condition. They always attributed that category to other people who would be "worse off", or deployed it when describing what they considered to be indicators of "poverty" - filth, for instance. The program's agents, on the other hand, worked with classifications and denominations that were part of their everyday practices and life experiences, and according to evaluations about the appropriate moment to deploy these markers. Different from most of the beneficiaries with whom we spoke, Maria Rosa did not have a family and personal history associated with "poverty", and neither did she have the skill to claim public services by performing this condition.

\section{Mine, yours, ours: money for "what is necessary"}

When asked about when and how they were led to apply for the PBF, all women referred to a moment when men - her partners or their children's father - became (deliberately or not) absent. As a rule, when informed about 
the program's eligibility criteria and the equations that determined poverty line thresholds, some women mentioned strategies of omitting income earned by their partners (whenever there was one). There was always the possibility of not mentioning to the agents the existence of male providers, and of making sure that the visits did not happen at a time when they were at home - thus avoiding to be caught in case they had lied about it. Two main reasons moved these women to "conceal" men and their income. Firstly, as Letícia explained, "they [government agents] may access [her husband] Rubens' SSN", and from then on "see everything" - their "debts", "wages", "how much he has in the bank", everything! Alternatively, it could be a strategy for obtaining the benefit without the partner's knowledge and interference in its management.

Rose, a married 31 year-old mother of two ( 14 and 16 years old), had been receiving the benefit for around four years. Her husband worked as an automobile mechanic. According to her, the benefit was used to purchase clothes and food: in her words, "not the bulk" (referring to basic staple items) but the "mixture" ("deli items" [cheese, ham], yogurt, meat, etc.). The "bulk", as well as the rent, light and water bills, were Gilberto's responsibility. When asked about why she did not include his name in the CadÚnico, at first she said, 'I'm not sure why. I just didn't. The woman asked if we were married or partners [stable domestic partnership]. If we were married, I'd have to hand her the documents. But we weren't, there was no paper. So I didn't include him". After a while, however, she explained that Gilberto would not let her "touch his money". He was the one who purchased the household goods, or, whenever she went along with him to the market, he made the payment and controlled her influence on what items could be bought. By not declaring her husband's name, she therefore secured some "cash of her own", since, as she declared, "it makes a difference that the card is under the woman's name. If it were under his name, he wouldn't give me anything. He doesn't really help me". Finally, she accused him of consuming certain products without sharing them with the rest of the family, since he only took responsibility for "bulk" items: "he eats everything, the good and the better, outside of the house".

In this respect, it is should be remarked that, since men were considered responsible for the "bulk", the PBF money was regarded as "an aid", normally

28 It is interesting to remark that this reference to "female money" as opposed to "male money" can be found in other income transfer programs, such as in Argentina: the Asignácion Universal por Hijo Para la Protéccion Social", as described by Hornes (2012). 
aimed at purchasing the "mixture" and items for the children: "better" school materials, clothes, and shoes. Another point in common among female beneficiaries living in Alvorada was the fact that they all referred to the program's cash as money "for the children" - managed by the mothers, but aimed at catering to the children's basic needs (food, clothing, and in some cases, medicine). According to another version, drawn from the ethnography carried out in the outskirts of Porto Alegre (but not necessarily associated with geographic factors), the PBF cash was also understood as money "for the children". But here, these funds were re-signified according to the logic of citizenship: they were regarded as children's rights, and a "reward" for meeting the program's conditionalities.

Vera was a young, 29 year-old married (or "living together", as she preferred) woman, mother of four children $(15,12,9$ and 6 years old). A resident of Ilha da Pintada (in Porto Alegre) for around ten years, she worked as a house cleaner in order to complement her husband's income. According to her, Gustavo was the "household head", because he "works", "leaves home 5 [a.m.] and only returns late at night". Since she became a beneficiary of the PBF around three years earlier, Vera dropped the cleaning service and became fully dedicated to household chores. She proudly explained that the "PBF income" allowed her "the privilege of taking the children to school", and also of "purchasing clothes and shoes for them". These items used to be bought only in Christmas time, but now they could buy them every month, if so they wished. Gustavo's job was informal, and that is why she preferred not to mention his monthly income to the CadÚnico. Every month, she received around $\mathrm{R} \$ 150$ (U\$64) from the PBF, and she believed that this money - which she defined as both "an aid from the government" and "a right of low-income citizens" - should be destined to those who do not have the privilege of a formal job or fixed income. This was precisely her family's situation upon enrollment in the program. Vera was unaware that she "had a right to the Grant" until she was invited for a temporary job as data collector for the CadÚnico in her neighborhood. Hired by an NGO which was in charge of registering all those who remained excluded from the program, Vera found out that the chief criterion was income rather than the fact of being a "single" or "divorced mother", as she believed to be the case up until then. This is exemplary of the gap between the PBF framework and the way it is effectively appropriated by the eligible and/or beneficiary public. 
Commenting on "inappropriate" uses of the benefit, Vera listed three things that should not be done with the PBF money: buying alcohol, cigarettes, and "leaving it with the husband". Vera managed both the program's cash and Gustavo's earnings, as well as gains from eventual cleaning jobs. Speaking of "appropriate" uses, she affirmed that, besides acquiring "better" clothes for the children, the PBF money provided the family with items such as better quality school materials, diversified and reliable foodstuffs (such as more meat, yogurt, and produce), an extra box of milk (12 cartons) every month, shampoo and conditioner for the girls, besides paying for one landline (social tariff), monthly cinema sessions, and, "little by little", for the materials necessary for enlarging the family's house ${ }^{29}$. For her, even though the money was under her care, it was in fact "of the children", since they were the ones abiding for the conditionalities by going to school "no matter what".

Nine-year old Bernardo was a "studious, hard-working" kid. As she told us, he was the only child who "really" enjoyed studying. The two girls, 12 and 15 , used to miss school every once in a while. In an attempt to motivate her children not to skip classes, she established that if, by Family Grant payday, there had been no unjustified school absences, they could all go for a stroll in downtown Porto Alegre, with the right to a movie session. Bernardo, who was hard-working and a movie lover, begun to control his sisters' school attendance. On a piece of cardboard attached to the kitchen wall, he would draw a monthly calendar adding an " $X$ " for each attendance and " $F$ " for each absence, next to the names of his school-age siblings. This panel, strategically located where everyone could see it, made sure that his sisters' school attendance was visible, thus providing the mother with a kind of control she did not have. The girls harassed and pinched him as a punishment, but according to Vera, they too began to attend school more frequently in order to avoid the penalty they all had to suffer if any one of them missed school.

Like Vera, 25-year old Valquíria stopped working when she enrolled in the PBF. Her husband worked as a fishmonger, and earned less than one minimal wage every month. When she worked as a house cleaner, she earned the same as her PBF benefit. She suffered from a series of health issues that she

29 When we met, she proudly mentioned that Family Grant funds had been invested in bricks and cement for "erecting two other rooms" in their house. They were not yet as she wished, however, because the floor was still "unfinished"; as she explained, she was "little by little" acquiring the flooring required for completing the house renovation works. 
attributed to the hard job as a cleaner, and so decided to stay home in order to take care of their 6-year old son Pietro. At that time, she was determined to resume her education, which she had quit when she got married: she enrolled in evening high school, and made plans to attend college. Valquíria wished to become a nutritionist. During the day, while her son went to public preschool and her husband worked at the fish shop, she took care of household chores and sold cosmetics in order to "enhance a bit" their family income.

For Valquíria, the PBF cash was for "buying Pietro's stuff". She declared that, in spite of recognizing that money as "her son's right" and an "extra income" that the government made available for him since his father's income was not fixed, sometimes the family had to use those funds when shopping for groceries - something that she tried to avoid whenever possible. Pietro used to come along with her on paydays, and he knew "that's his money": he demanded toys, clothes, shoes, and candy. The month before our meeting, the boy had "forced" her to "purchase a Ben 10 [cartoon character] sweatshirt". She agreed because she acknowledged that the family's "make do" in fact belonged to the child. Whenever they were able to pay their bills without the need to "touch" the PBF money, they put whatever was left in a piggybank that the boy had got from his grandmother. The money saved there was used at the end of the year to supplement family funds dedicated to trips to the beach and "leisure" in general. Like her, Ivânio "does not have the guts to spend the Grant money". Once, she recounted, the father needed $\mathrm{R} \$ 50(\mathrm{U} \$ 21)$ in order to pay a late bill. He took Pietro’s piggybank, called him to the kitchen table, explained what was going on, and "asked to borrow that amount". Upset, Pietro threw himself on the floor, cried and showed his discontent for the proposal; but he eventually agreed, after the father guaranteed that that value would be returned by the end of the week. Unable to do so, Ivânio had to borrow from a co-worker in order to "pay back" Pietro. Even though this narrative may have been overstated in some respects, it is still significant. The PBF money may not be entirely exclusive to the child, but is at least idealized as such.

The cases presented here share a belief that the PBF cash should be managed by the women, and, provided that there is another source of income "for the bulk", it is should be spent on the children's needs - or, depending on the family's finances, by the children themselves. At another level, the PBF cash appears again as a kind of female money, being appropriated for 
purchasing the "mixture", the fine (as opposed to the "bulk"), that is, items considered superfluous but no less indispensible.

But for many other beneficiary families, the PBF is the sole (or most regular) source of income. In these cases, men/fathers are either unemployed (if not entirely absent) or unable to provide for their families. The PBF money thus becomes a kind of resource aimed at basic provisions. Men may react to this violently - by "stealing” the women's money - or by becoming themselves its managers. In both cases, women feel abused and wronged, since they understand that those funds are directed, above all, to them.

Viviane was a 27 year-old mother of three (12 and 10 years old, and a 2-month old baby). She told us that her partner was the cardholder, and indeed this fact was the object of gossiping in the neighborhood. Jandira, her neighbor, once mentioned that Paulo César "had prevailed" because Viviane was illiterate. She believed that the cardholder should always be the woman, but the husband had taken advantage of his wife's ignorance. When asked about the value of their benefit, Viviane guaranteed that they received around $\mathrm{R} \$ 40$ (U\$17) - which is highly unlikely, since this amount is less than the program's minimum. Five people lived in her four-room house: herself, the three children, and the husband, 32-year old Paulo César, with whom she had been for 14 years. He worked as a recycler, and, as she explained, the purchase of a horse for "pulling his cart" triggered a lot of "gossiping" among neighbors. For her, the Family Grant money should go to the women and the children, as her neighbors had warned her. Paulo César thought, however, that the money should be directed to the needs that he identified. Thus, when his horse died, he used the Grant money to finance the purchase of another animal. He made a deal with an acquaintance who, because of that "guaranteed money", accepted to sell him the horse through monthly installments. As she explained, the money wasn't always under her husband's responsibility. Previously, she was the one who managed it; she would then buy "food and sandals for everyone. When I did it, it was a sure thing".

This particular case brings to surface how some men appropriate the benefit. Paulo César was criticized not only because he kept the card, but especially because, when using it, he deviated the funds to ends that their neighbors deemed inadequate. Like other female interlocutors, Viviane and her neighbors viewed the Grant as money to be spent on "necessary” items, 
but not necessarily on what they called "bulk items". The "bulk" should be men's responsibility. Viviane expressed her dissatisfaction with the fact that she became unable to buy sandals for the children or the "mixture" (cheese, ham, cookies and candy). According to her, Paulo César was unaware of what the children liked to eat, and how long these items would last. She used to shop for household items (including groceries) every week, while he was doing it once a month.

We met Edna through Paula, who ran Alvorada's preschool. A 25-year old mother of two girls ( 9 and 7 years old), she had been facing financial difficulties since her partner was jailed. Her daughters had opposite school schedules, what made it difficult for her to have a fixed job. Sometimes Edna had permission from some of her "bosses" to bring one of them along with her, but since all her cleaning jobs were in Porto Alegre, she was always late to drop off or pick up the other in school. After Manuel was arrested, Edna's family, and then his own relatives, moved from the neighborhood in order to avoid the shame caused by the crime (Edna never mentioned him), and due to the fact that she continued to visit him in jail. She found in Paula the muchneeded support for overcoming the obstacles involved in conciliating a job and the care of her children. They negotiated a value that was fair for both of them, and Edna offered the PBF money as guarantee. As she explained, before Paula began to "take care" of her children, her "card was blocked" three times because she had failed to keep her daughters attending school regularly, or to satisfy some other conditionality. With Paula making sure that the children attended school and conditionalities were all met, Edna destined the full value of the grant to the school: "I leave it all at the school", she said. This way, she could continue to work as a cleaner during the weekdays and on Saturdays, thus tripling her income.

Like Paulo César's, Edna's PBF money was therefore directed at supporting her productive activities. While she deployed it in order to make sure that her children would stay in school and meet the program's conditionalities, thus allowing her to keep working as a house cleaner, he acquired a new horse in order to keep working as a collector of recyclables. The difference lay however in the legitimacy attributed to that spending. While Edna was praised as a "strong", "hard-working" woman, Paulo César was accused of inappropriately taking his wife's card (a fact that has not been confirmed) and of "not buying one carton of milk for the children". 
The relevance of different "poverty" trajectories should also be taken into account. Even though most of our interlocutors grew up and lived much of their lives under dire socio-economic conditions, as was indeed the case with most PBF beneficiaries, there were some exceptions. Maria Rosa, for instance, "had been" poor for around 13 years. Although she lived in a middle-class neighborhood in Porto Alegre, and had "everything she needs at home", she had to manage her scarce resources very carefully. The apartment where she lived with her daughter had two bedrooms, kitchen, bathroom, and a large living room. The furniture was a relic of the "good times", and was kept intact because most items were untouched or protected with a plastic cover. Maria Rosa had discount on her light and telephone bills, but in order to save further she used to keep the lights off (some of the rooms didn't even have light bulbs) and only used the telephone for receiving calls. Her daughter attended public school, in accordance with the family's "reality". Her efforts to save went beyond the light and telephone bills: neither of them purchased clothes (including underwear). She also showed concerns about the gas stove, only cooking what was strictly necessary and privileging foods that could be eaten raw. According to her calculations, during the winter it was cheaper to heat their bath water on the stove than using the electric shower. Commenting on the fact that they only wore second-hand clothes, Maria Rosa conceded, "there are those who care, who think it's bad [laughter]. We don't mind. I don't buy anything, not even panties. It's all second-hand. What else can I do?". And she completed, "at least we have a lot of stuff, a lot of clothes, underwear, socks... some people are worse off than us! We cannot complain". Her daughter Gabriela's school materials were also donations. Whenever she gained notebooks, Maria Rosa ripped off the used sheets so that the girl could use the rest of it - as she put it, "we keep on recycling".

When we talked about the discomfort her daughter experienced at school - according to her, due to the evident economic disparity between her and the other students -, she remarked that the girl was laughed at "because of her panties". "Last thing", she recounted, she was bullied for not shaving "but beauty salon is superfluous ... I don't go to any". Showing her hands, she explained that she painted her fingernails at home. Similarly, she removed her body hair using tweezers, and Gabriela began to do the same in order to placate the bullying at school. Just like other beneficiaries, Maria Rosa believed that the benefit should be directed to her daughter, but she still 
imposed further restrictions on the way it was spent: "the PBF money is for food. I think it should be specifically for her, but in order to buy food, not superficialities".

Of all female (or male, in the case of Paulo César) beneficiaries mentioned here, Maria Rosa was perhaps the only who strictly directed the PBF cash to expected ends. Yet, in all cases, the way the money was spent was justified based on "needs" - although the very notion of what was "necessary" seemed to have been broadened by the introduction of the PBF money into the household economy of low-income families.

Effectively, the moral configuration assembled around the PBF money may vary according to other ways of organizing and adjusting, for instance, within domestic nuclei and in the compositions and interactions that take place within the broader social protection network. With respect to domestic configurations, the cases brought here orbited not only around the absence or presence of men/fathers (always a frequent topic in discussions about the program's target group), but around their occupations and the effective role they played in providing for their families. Similarly, the trajectory of "poor" beneficiaries significantly refracted the understandings and attributions addressing that kind of money. Families whose social and economic conditions have undergone positive changes allow themselves the privilege of acquiring goods and consuming items that did not figure among their previous priorities. On the other hand, the beneficiary who had been "rich", who once had "all that is good and better", came to regard the PBF money as a possibility for maintaining at least her basic dignity once she became "poor". As we understood it, this attitude is revealing less of the benefit's purchasing power than of the fact that it protected the beneficiary from exposure to the job market and the kind of judgment that she would likely face. To save, "prioritize", acquire "only what's strictly necessary" were not exclusive to Maria Rosa. The difference is that most beneficiary families found a way of extending the domain of the "necessary": leisure, "brand" clothes, yogurt, an extra box of milk at the end of the month, a portion of meat instead of the usual pack of frankfurters, or shampoo specific for one's hair type. These privileges, which belonged to a few, became ordinary after the PBF. In other words, once it became accessible, what used to be "superfluous" became "necessary".

It is precisely the perspective of having a "guaranteed" income at the 
end of each month that opens up, for some beneficiaries, new possibilities not only in terms of consumption but of work and production (in spite of a persistent fear of "losing the grant" - which stems not only from a view of it as not being a right, but also from the difficulties that most people face when trying to making sense of the program's bureaucratic intricacies). Exemplary of this claim was the beneficiary who offered the full grant as payment for her two daughters' care, therefore making viable her regular participation in the job market.

\section{Concluding remarks}

By reformulating and consolidating in the PBF the various cash-transfer programs that channeled resources to the poor, the Brazilian government implemented a bold strategy. Not only did it increase spending and the number of beneficiaries - it also monetized the benefits. To deliver money on the hands of the poor seemed too risky. If this were no more than a clientelistic strategy, it would have made more sense to maintain gifts associated with goods; the classic sociological literature tends, after all, to emphasize the impersonal character of money. The personal character of transactions, it is worth recalling, is one of the key elements in economies based on conventional gift giving. The Lula government's public relations did succeed however in associating the PBF with that particular administration, by rendering ineffective the opposition's attempts at highlighting the fact that most CCTPs existed previously to, and were in fact the embryo of, the PBF. Yet, the visible commotion around the program in the conservative media, where Brazilian society's most elitist segments express their opinions, reveals class prejudices and stereotypes that transcend national borders. The conviction that the poor are incapable of managing their own lives, not the least managing cash, is so widespread as rendering meaningless any effort at retracing its spatial or temporal socio-genesis. Given that money is a universal mediator, and therefore easily reconverted, the beneficiaries' room for maneuver is relatively broad, as the ethnographic instances brought here illustrated. Even though the benefit value lags behind the dire needs of families living below the poverty line, significant room for maneuver was found in how they accessed and effectively deployed the program's cash benefit. This is unsettling for many, and those who do not admit the possibility of granting them that kind 
of freedom have always criticized the PBF. The ethnography showed however that not many beneficiaries view the PBF from a public policy perspective, nor the money they receive as constituting a right. The notion of aid - even if from the government - is still pervasive among them, but it is even more so among the program's critics. For the neoliberal imaginary, public policies are often regarded with suspicion, and the fact that a benefit granted by the state may be used with some degree of freedom sounds like an aberration. ${ }^{30}$ But in fact, between the PBF framework and its effective implementation there are multiple mediators. These are mediators of a specific kind, engendered by the program itself. As remarked in the introduction, during the transformation of the early Brazilian cash-transfer programs into the PBF there was explicit concern with reducing bureaucratic and political mediations. Why, then, we resume this issue in order to conclude in an apparently opposite direction, suggesting that the PBF has multiple and specific kinds of mediators?

Firstly, the PBF provides cash; not a lot, but still, cash. As is well known, money is an important mediator in our society. If a woman - and here it is necessary to decline the gender, since it is one of the PBF's chief characteristics - receives a stamp for milk or gas, her leeway for making further mediations based on these goods is much smaller than if she had received the equivalent in cash. Money obviously stretches possibilities not only for consumption but for negotiation, as was shown early on through the cases of Edna and Paulo César. Edna handed over the PBF money to the school so that her daughters would be taken care of while she worked as a cleaner and thus enhanced her income. Paulo César offered the PBF benefit as guarantee in order to purchase a horse by installments - even if this was a controversial attitude from the point of view of his neighbors.

Secondly, by offering cash, the PBF strays from conventional welfare programs for the poor towards labor protection policies, such as those that secure minimal income regardless of whether the subject is employed (minimal wage) or not (unemployment insurance, retirement, pensions,

30 As the contemporary literature has emphasized (ZELIZER, 2005; HART, 2007), the PBF grant lies, in a sense, on an ambiguous terrain between the poles of the personal and the impersonal. Many claims against the program underscore that its budget is ultimately sustained by other citizens, thus reintroducing in the debates the question of its personal character. In any case, the ethnographic experience underlying this study does not allow us to delve further into this issue. But that does prevent us from calling attention to the potential productivity of discussions on relations between the public and the private, the personal and the impersonal, the sacred and the profane, freedom and conditionality, and so forth. 
and so forth). The PBF delivers money to people who are not regular, formal workers - which does not mean they do not work. This is a controversial point, and thus the need for discursive mediations. To grant an elder, a widow or a handicapped a government pension seems less liable to justification than money received through the $\mathrm{PBF}$, even if these funds come from the same source. This unevenness stems largely from views regarding the moral value of work in society at large. The PBF touches that nerve, by establishing a triangular relationship between extreme poverty, money, and conditionalities.

Once again, money appears as a mediator, for which poverty is the front door and conditionalities are the living room. There is no exit door, however, and indeed the PBF has not been conceived from this perspective. Most important for our argument is the fact that the conditions for staying in the program are associated less with the conventional meaning of work than with compliance with conditionalities that are part of women's responsibilities: care of the children. Thus, there are extreme cases such as that of Cigana, where the precariousness of living conditions (among which, poverty) is such that provides little room for maneuver. In others cases, it is possible for women to use the PBF as leverage in their management of tasks that are socially considered to be their responsibility: to take care of the children and of the household budget. In certain circumstances, it is even possible to become financially independent from their partners.

As is well known, the program prioritizes women as cardholders, on the grounds that they are more apt at managing the domestic economy. It correspondingly tends to consider women as being more "vulnerable", since they face more obstacles for entering the formal job market, and normally keep the children in case of divorce. If, on the one hand, the PBF is generous to women, on the other it reaffirms certain attributions and stereotypes. It is based on the assumption that men/fathers are absent or, when present, that they are unable to take responsibility for caring for the family in the same way as women do. By prioritizing women/mothers, children and adolescents, the program's guidelines take male absence and/or lack of responsibility for granted in the case of families considered "vulnerable". Our female interlocutors understood this well, and played with that possibility either in order to access the benefit more easily, or in order to gain the opportunity to manage a kind of income that lies outside of their partners' reach. Men, on their turn, seemed to understand and feel the weight of moral reproach, since to receive 
the PBF is to acknowledge failure to provide for one's family - thus their feeling of dishonor and uneasiness before the social workers.

The ethnographic account presented here aimed at showing, moreover, that management of the PBF benefit is not random. It was not our concern whether the money was applied or not according to the program's guidelines - a question that has been the object of curiosity both within and without academia. Rather, what moved us was a typically anthropological interest on the meanings of this kind of money, and how they were constructed through the articulation of different worlds. The "poor" definitely do not spend their money on the first thing they see - or, better said, even if they do, they do so through the mediation of symbolic lenses shaped by moral values that are being constantly tensioned. Not all spend that money appropriately, according to the PBF beneficiaries' own views, but all have a precise idea of how they should proceed, and even of the leverage for negotiation that is available to them. What seems certain is that this is a special kind of money. It is marked since its origin: while allowing for mediation, as other kinds of money do, it is charged with a moral aura. It is everywhere identified as money for women and children, and it is in relation to them that its deployment is publicly judged and labeled as "good" or "bad".

During fieldwork, two points about the PBF became evident. First, it was a topic that caused uneasiness. People avoided talking about it, and, whenever they did, they were quite cautious. When asked about their knowledge of "misuse" (a common topic for gossiping), everyone would remember one case or another, sometimes elaborating on what exactly would this inadequate use be. But the person being talked about would never be part of the speaker's relations - when inquired further, the latter would just say that "they live down there", "right there", waving vaguely towards the lengthy road, thus making it difficult to double-check that kind of information. Secondly, whenever beneficiaries were asked about what they did with the amount they received every month - that is, about the benefit's purchasing power - they would normally list items that, when summed up, could exceed in up to $200 \%$ the actual value of the benefit. There are two possibilities in this respect: either they were underdeclaring the value of their PBF benefit, or that money was being conflated with other kinds of money, coming from different sources. Although the first possibility cannot be ruled out, we are led to believe that in general 
the PBF money ends up being conflated with other income as well as nonmonetary resources coming from elsewhere. This means that the moral surveillance over expenses is not directed exclusively at the PBF benefit, but targets the ensemble of the beneficiaries' earnings and expenses, including their behavior.

In terms of the ideas that were discursively manifested, what "must not" be done with the PBF money seemed well established: alcoholic drinks, cigarettes, drugs, gambling, superfluous foodstuffs (sweets, soda, unhealthy snacks), toys (especially when the family was considered very poor), domestic appliances, telephones, lipstick, and so forth. All these items were considered inappropriate, and even though people living in the neighborhood arguably purchased them, these individuals were never identified. There is however one way of spending the Family Grant cash that, even though not regarded as the most appropriate by the families, was common among them. Different from the abovementioned items, this was not expressed as something that "must not" be done; it was, rather, something to be avoided but which, depending on the family's situation, may be done. As the women declared, they (and some of the men) believed that the PBF cash was "for the children", and must be spent "on them" and "on their behalf". If the program's income was deployed for covering bills from the family at large, such as gas, food (that is, the "bulk", or basic staples), medicine, water, light, rent, etc., it was due to its dire financial condition (which was usually presented as temporary) and still, an effort was made so that at least part of it was spent directly on the children.

"It's for the children's mill" was a reference as common as "I spend it all on school materials", or yet, "that money is all for them [the children]" - even while those same people also declared that they used the benefit in order to purchase other products (besides the ones directed to the children) or pay household bills. It is important to remark that these statements were heard in contexts where the beneficiaries were being asked about what they considered to be appropriate ways of spending the PBF benefit. When inquired about what they actually made of it, however, they would normally mention the following items: rent, light, water, food (basic staples), school materials, shoes and clothes for the children (there was no reference to clothes or shoes for themselves), and stove gas. These items were mentioned by both the female beneficiaries and by the social workers, when asked about it. 
In other words, the beneficiaries knew exactly what was expected from them when spending the PBF money, even if the program itself did not specify it. Fieldwork at Ilha da Pintada (Porto Alegre) lent further credence to this hypothesis, especially since that locality enjoyed more and better public services than Alvorada. In the Ilha, there were less agents from other (nongovernmental) agencies taking part in program implementation and the "monitoring" of beneficiaries - their intervention in the life of beneficiary families being therefore less forceful and frequent.

When asked about what they considered to be appropriate and inappropriate uses of the PBF money, the Ilha residents' answers did not stray significantly from those found in Alvorada, especially with respect to the importance of children. It was there that, for the first time, we heard a PBF beneficiary affirm that she used the benefit for leisure, "brand" clothes, and even in order to "save a little". It is curious however that all these answers were still associated with the children. The main difference was in the fact that, for the beneficiaries from Alvorada, the money was "for the children" (that is, it catered to their needs), while for those in Ilha da Pintada, the money was "of the children", or directed to them as a kind of "reward" for appropriately complying with the program's conditionalities. When asked however about what they effectively did with that benefit throughout the month, answers varied. It was used, for instance, to "take the children to the movies" when "they carried out the task of attending school" that month - or yet, "he [the son] knows that the [BF] money is his, and when payday comes he knows that he can ask for an item of clothing or pair of shoes because I am obligated to buy it for him". Some have also declared to have no "guts" to spend the money on themselves, because it belonged "to the children".

Although it dispenses with intermediaries between the cash and its final recipient, the BF grant - understood in this account as money of a "special kind" - requires the presence of agents from various modalities and spheres of intervention. Originally thought of as being primarily refracted by gender and class - money for women and of/for the poor -, this kind of money eventually appeared as traversed by multiple social relations, based on different modalities of power and hierarchy. Likewise, beyond the meanings it acquires during the establishment of program guidelines, that money is continuously re-signified during its journey to the homes of beneficiary families, as it enters the complex process of implementation. There, it receives 
new meanings and hues that flow from domestic configurations and from expectations and moral ideas concerning family and gender relations. From this assemblage of relations, different moral configurations emerge which coexist and intersect with each other, thus inviting for an analysis in terms of a "moral economy" which nourishes and mobilizes emotions, values, norms, and obligations that transcend the domain of the Family Grant Program itself.

Translated from the Portuguese by Leiticia Cesarino

Receoved October $14^{\text {th }}$ 2013, approved December $10^{\text {th }} 2013$

\section{Works Cited}

ÁVILA, Milene Peixoto. 2013. O Bolsa Familia e a pobreza no Brasil: "detalhes" que fazem a diferença. Tese de Doutorado, PPGCS , UNICAMP, Campinas.

BIEHL, João. 2013. "The judicialization of biopolitics: Claiming the right to pharmaceuticals in Brazilian courts". American Ethnologist, 40(3): 419-36.

BRASIL. 1993. Lei Orgânica de Assistência Social. LOAS - Lei № 8. 742, de 7 de dezembro de 1993.

COHN, Amélia. 2012. Cartas ao presidente Lula: Bolsa Familia e direitos sociais. Rio de Janeiro: Pensamento Brasileiro.

EGER, Talita Jabs. 2013. Dinheiro e moralidade no Bolsa Familia: uma perspectiva etnográfica. Dissertação de mestrado, Programa de Pós Graduação em Antropologia Social - UFRGS. Available at: http://www.lume.ufrgs.br/ handle/ $10183 / 81383$

FASSIN, Didier; EIDELIMAN, Jean-Sébastien. 2010. La raison humanitaire - une histoire morale du temps présent. Paris: Hautes Études/ Gallimard/ Seuil.

FASSIN, Didier; EIDELIMAN, Jean-Sébastien. 2011. La force de l'ordre - une anthropologie de la police des quartiers. Paris: Seuil.

FASSIN, Didier; EIDELIMAN, Jean-Sébastien. 2012. "Introduction.

Défense et illustration des économies morales”. In: Économies morales contemporaines. Paris: La Découverte. pp. 19-52.

FASSIN, Didier; EIDELIMAN, Jean-Sébastien. 2012. "Vers une théorie des économies morales”. In: Didier Fassin e Jean-Sébastien Eideliman (orgs.), Économies morales contemporaines. Paris: La Découverte. pp. 19-52.

FONTAINE, Laurence. 2008. L'économie morale. Pauvreté, credit et confiance dans l'Europe préindustrielle. Paris: Gallimard. 
FUNDAÇÃO DE ECONOMIA E ESTATÍSTICA. 2013. Disponível em: http:/| www.fee.tche.br/sitefee/pt/content/resumo/pg_municipios_detalhe. php?municipio=Alvorada. Acesso em 2 de agosto de 2013.

HART, Keith. 2007. "Money is always personal and impersonal”. Anthropology Today, 23: 12-16.

HORNES, Martín. 2012. "El dinero en feminino. Las construcciones sociais del género y su incidência em las practicas económicas de los hogares receptores de programas de transferências monetárias condicionadas”. In: Anais VII Jornadas de Estudos Sociais de La Economia: El carácter social de los processos y objetos económicos. Buenos Aires.

MDS. 2013. Relatório de Informações do Bolsa Familia e Cadastro Único para Programas Sociais do Governo Federal/2012. Disponível em: http:// aplicacoes.mds.gov.br/sagi/RIv3/geral/relatorio_form.php?p_ ibge $=430060 \&$ area $=0 \&$ ano_pesquisa $=\&$ mes_pesquisa $=\&$ saida $=$ pdf $\&$ relato rio $=153 \& m s=585,460,587,589,450,448,464,601$. Consultado em o 4 de abril de 2013.

MEDEIROS, Marcelo.; BRITTO, Tatiana.; SOARES, Fábio Veras. 2008. Targeted cash transfer programmes in Brazil: BPC and the Bolsa Família. Brasília: IPC (Working Paper n. 46). Disponível em: http://www.ipc-undp.org/pub/ IPCWorkingPaper46.pdf

MELLO, Kátia Sento Sé. 2011. “O sofrimento como recurso de acesso ao direito: efeitos da política de recadastramento dos camelôs em Niterói”. In: Cidade e conflito: guardas municipais e camelôs. Niterói: Editora da UFF. pp. 161-189.

MÜLLER, Lúcia Helena . 2009. “Então eu fui à luta!”: repensando as representações e práticas econômicas de grupos populares a partir de uma trajetória de ascensão social. Política \& Sociedade, 8: 145-171 POCHMANN, Márcio 2010. "Apresentação. Instituto de Pesquisa Econômica Aplicada”. In: Jorge Abrahão Castro; Lúcia Modesto (orgs.), Bolsa Familia 2003-2010: avanços e desafios, vol. 1. Brasília: IPEA. pp. 7-11.

RABELO, Maria Mercedes. 2011. Redistribuição e reconhecimento no Programa Bolsa Familia: a voz das beneficiárias. Tese de Doutorado, PPG Sociologia, UFRGS, Porto Alegre.

SANT'ANA, Sarah Mailleux. 2011. A perspectiva brasileira sobre a pobreza: um estudo de caso do Programa Bolsa Familia. Available at: http://www.ipc-undp. org/publications/mds/24M.pdf. Last accessed, January 11, 2011. 
SANTOS, Judit Camilo dos. 2007. Familia, parentesco e política: um estudo da implantação do Programa Bolsa Familia em um município do Vale do Ribeira, PR. M. A. Thesis, Programa de Pós-Graduação em Antropologia Social, UFPR, Curitiba.

SILVA E SILVA et alli. 2008. A política social brasileira no século XXI: a prevalência dos programas de transferência de renda. São Paulo: Corteza.

SILVA E SILVA, Maria Ozanira. 2009. "Programas de transferência de renda: uma renda básica de cidadania e uma renda mínima condicionada (entrevista especial com Eduardo Matarazzo Suplicy)”. Revista Políticas Públicas, 13(12): 231-240.

SOARES, Sergei; SÁTYRO Natália. 2009. "O Programa Bolsa Família: desenho institucional, impactos e possibilidades futuras”. Texto para Discussão no 1424. Brasília: IPEA. Mimeo.

WEBER, Florence. 2006. "Lares de cuidado e linhas de sucessão: algumas indicações etnográficas na França, hoje”. Mana. Estudos de Antropologia Social, 12(2): 479-502.

WILKIS, Ariel. 2013. Las sospechas del dinero - moral y economia em la vida popular. Buenos Aires/ Barcelona/ Mexico: Paidós.

ZELIZER, Viviana. 1994. “Circuits within capitalism”. In: Victor Nee \& Richard Swedberg (eds.), The economic sociology of capitalism. Princeton: Princeton University Press. pp. 289-321.

ZELIZER, Viviana. 2003. "O significado social do dinheiro: 'dinheiros especiais”'. In: Rafael Marques; João Peixoto (orgs.), A nova sociologia econômica: uma antologia. Portugal: Celta Editora. pp.125-165.

ZELIZER, Viviana. 2005. The social meaning of money. New York: Basic Books.

ZELIZER, Viviana. 2011. A negociação da intimidade. Petrópolis: Vozes.

ZELIZER, Viviana. 2012. "Dinero, circuito, relaciones íntimas”. Sociedad y Economía. pp. 11-33. Disponível em: http://dintev.univalle.edu.co/ revistasunivalle/index.php/SyE/article/view/1726/1650. Acesso em 01 de agosto de 2013 . 